\title{
Silver Nanoparticle Modified Graphene Paste Electrode for the Electrochemical Detection of Lead, Cadmium and Copper
}

\author{
Shirley Palisoc ${ }^{1,2}$, Eldrin T. Lee ${ }^{1}$, Michelle Natividad ${ }^{* 1,2}$ and Lotis Racines ${ }^{1,3}$ \\ ${ }^{1}$ Condensed Matter Research Laboratory, Physics Department, De La Salle University \\ ${ }^{2}$ Condensed Matter Research Unit, CENSER, De La Salle University \\ 2401 Taft Avenue, Manila, Philippines, 922 \\ ${ }^{3}$ Central Mindanao University, Maramag, Bukidnon, Philippines, 8714 \\ *E-mail: michelle.natividad@ dlsu.edu.ph
}

doi: $10.20964 / 2018.09 .03$

Received: 23 March 2018 / Accepted: 30 June 2018 / Published: 5 August 2018

Silver nanoparticle (AgNP) graphene paste electrodes were fabricated from graphene powder mixed with mineral oil and silver nanoparticles. Anodic stripping voltammetry (ASV) was utilized to simultaneously detect lead $\left(\mathrm{Pb}^{2+}\right)$, cadmium $\left(\mathrm{Cd}^{2+}\right)$ and copper $\left(\mathrm{Cu}^{2+}\right)$. The optimized amounts of mineral oil and $\mathrm{AgNP}$ were $80 \mu \mathrm{L}$ and $2 \mathrm{mg}$ respectively. The calibration curve of the optimized electrode showed a strong line correlation between the heavy metal concentration and the reduction current for $\mathrm{Pb}^{2+}, \mathrm{Cd}^{2+}$, and $\mathrm{Cu}^{2+}$. In addition, the limit of detection is 17 parts per billion (ppb) for $\mathrm{Cd}^{2+}, 12 \mathrm{ppb}$ for $\mathrm{Pb}^{2+}$ and $44 \mathrm{ppb}$ for $\mathrm{Cu}^{2+}$. The optimized electrode was tested on three commercial brands of Puerh tea. Copper metal ions, $\mathrm{Cu}^{2+}$, were found in the tea samples. Lastly, atomic absorption spectroscopy was used to verify the results obtained from ASV.

Keywords: Silver nanoparticle, graphene paste electrode, anodic stripping voltammetry, heavy metals

\section{FULL TEXT}

(C) 2018 The Authors. Published by ESG (www.electrochemsci.org). This article is an open access article distributed under the terms and conditions of the Creative Commons Attribution license (http://creativecommons.org/licenses/by/4.0/). 